Biological and Clinical Sciences Research Journal

ISSN: 2708-2261

www.bcsrj.com

DOI: https://doi.org/10.54112/bcsrj.v2020i1.27

Biol. Clin. Sci. Res. J., Volume, 2020: 27

Original Research

\title{
EFFECTS OF HEAVY METAL TOXICITY ON MAZE SEEDLINGS GROWTH TRAITS
}

\author{
SHAFIQUE F, *ALI Q, MALIK A
}

\author{
Institute of Molecular Biology and Biotechnology, The University of Lahore, Lahore, Pakistan \\ Corresponding author: saim1692@gamil.com
}

(Received, $10^{\text {th }}$ March 2020, Revised $7^{\text {th }}$ September 2020, Published $16^{\text {nd }}$ September 2020)

\begin{abstract}
Maize is an edible cereal crop that belongs to family Gramineae and use as an energy source for human and animals. In our country the industrial and municipal wastewater has been being used for irrigation purposes that contain heavy metals. These heavy metals affect production of maize crop and soil quality. The purpose of this study was to investigate the affect of different heavy metals on maize growth and to asses more tolerant and more sensitive maize variety. Different concentrations of $\mathrm{Mn}$ and $\mathrm{Cr}$ (0, 0.25Molar, 0.50Molar) were applies in combined form and individually. Total three replicates were carried out during research. Analysis of variance (ANOVA), Tukey's rang test $(p \leq 0.05)$ were applied as statistical tool among treatment means. ANOVA indicated the differences among five different genotypes and 9 different treatments for all parameters were significant. Tukey's test indicated that higher toxic effect was shown under treatment $0.5 \mathrm{M} \mathrm{Mn}+0.25 \mathrm{M} C r$ while less toxic effect was observed under treatment 0.50M Mn in maize plant. The genotype $31 R 88$ was more sensitive for metal toxicity because most of $31 R 88$ traits were affected under heavy metal treatments while more tolerant variety was Neelum. Hence the results of our study have suggested that the genotype Neelum may be used for the improvement of grain yield and productivity under heavy metal stress conditions.
\end{abstract}

Keywords: maize, heavy metals, analysis of variance, Tukey's rang test, 31R88, Neelum, tolerant variety

\section{Introduction}

Most of the heavy metals are occurred in fertilizers, pesticides, municipal and compost wastes and naturally in earth crust but when they are released in excess concentration into the environment due to anthropogenic activities they affect plant growth and human health (Rakesh et al., 2013). Industrial and municipal wastewater contain less concentration of heavy metals but long term use of these wastewaters for irrigation purposes can affect the plant growth and restrict soil function. Most of the plant roots help in immobilization of heavy metals but excess concentration of heavy metals such as $\mathrm{Cd}, \mathrm{Cr}, \mathrm{Cu}$, $\mathrm{Co}, \mathrm{Ni}, \mathrm{Zn}$ become toxic for plant growth (Ashfaque et al., 2016). Now a days heavy metal accumulation is a big problem in our world. These heavy metals accumulated into the plant bodies directly or indirectly. They inhibit the physiological processes. High concentration of heavy metals in our atmosphere might be resulted from agricultural activities, industrial processes, mining activities and emission from vehicles (Salt and Rauser, 1995). Maize is considered as main food source for living organisms and main energy source in developing countries (Chaudhary, 1983; Ali et al., 2014ab; Ali et al., 2015; Ali et al., 2016; Ali et al., 2017; Ashraf et al., 2020). Most of the metals are very toxic in low concentration like $\mathrm{As}, \mathrm{Pb}, \mathrm{Hg}, \mathrm{Cd}$. But most of the metals are require in small amount for plant growth, excess concentration can inhibit physiological processes (Raskin et al., 1994). Essential metals like $\mathrm{Fe}, \mathrm{Cu}, \mathrm{Zn}, \mathrm{Mg}$ are involved in biochemical processes. Most of the heavy metals are occurred in industrial wastewater, when they discharge into surface water they cause serious health damages (Mohnish and Kumar 2015; Zubair et al., 2016). In Benin city most of the dump sites are used for agriculture purposes. Some farmers used decomposed materials from dump sites and apply them on crops as manure which contains heavy metals. Plants uptake these metals that are unfit for plant growth and human consumption (Demirevska et al., 2004). Metals like mercury, lead, cadmium and arsenic are toxic at very low concentrations (Nkansah et al, 2010). Though most heavy metals are needed in trace amounts by growing plants, their excess can result in plant intoxication. The occurrence of heavy metals in industrial wastewater is of interest because they are often present at significant levels and if discharged into surface waters can have severe effects on the environment and public health. Thus the presence of concentrations of heavy metal in plant tissues brings about poisoning problems in human beings and other animals feeding on specific plant tissues (Mazhar et al., 2020; Saif-ul-Malook et 
al., 2014; Tahir et al., 2020; Zubair et al., 2016; Shan et al., 2014; Sheng et al., 2008). These heavy metals have the potential hazardous effect, not only in compounds but also on human health. This is due to their cumulative properties and toxicity although they are generally present in agricultural soils at low levels. Increasing industrialization has been accompanied throughout the world by the extraction and distribution of mineral substances from their natural deposits. However, there are large scale industries in Pakistan, both privately and publicly owned. These include cement, pharmaceuticals, paint, ceramics, roofing sheets, agro allied, beverages and so on. The auditing and monitoring of metals in the environment (soil, water and foods) is fast becoming an essential aspect of pollution studies, particularly in industrialized area.

\section{Material and method}

Seeds of five different maize accessions were sown during summer season in soil filled plastic pots.

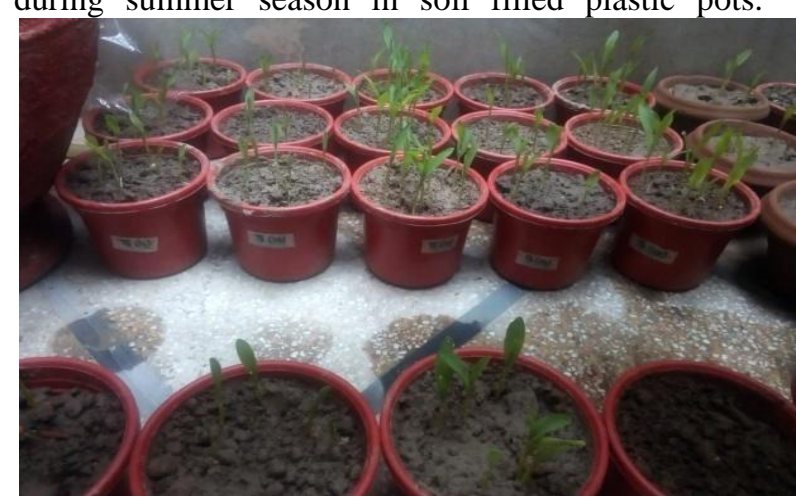

Figure

\section{Results and discussion}

It was persuaded from results given in table 1 that there were significant difference among maize genotypes, treatments of heavy metals and interactions between genotypes and treatments of heavy metals. It was found that there was very low coefficient of variation for all growth parameters indicated that there was higher consistency for all these growth parameters. The results from table 2 indicated that there was high number of leaves per plant, leaf area, fresh stem weight, dry leaf weight and diameter of root was found for genotype Neelum while low plant height, leaf area, dry stem weight, dry root weight, dry leaf weight, fresh stem weight, fresh root weight, fresh leaf weight and diameter of stem was found in genotype 31R88. The high number of leaves per plant, leaf area, fresh stem weight, dry leaf weight and diameter of root indicated that there were higher photosynthetic compounds in the leaves which may be helpful for the improvement of organic compounds accumulation in the leaves and provides resistance against various abiotic stresses (Ali et al.,
Seeds were washed with distilled water before sowing to remove contamination. Total seven seeds were sown in each pot. Metals ( $\mathrm{Cr}$ and $\mathrm{Mn}$ ) were applied individually and in combined form. One set was treated as control. Water was applied according to requirement.. Soil was turned over on regular basis. Three replicates were carried out at a time. Plants were harvested with the interval of ten days. Data was recorded carefully. Plant height and leaf area was measured with the help of meter rod. Diameter of root and diameter of stem was measured with vernier caliper. Fresh weight $t$ of root, stem, leaf was measured by using electric balance. After weighing the fresh weight of root, stem and leaf, they were kept in oven at $40^{\circ} \mathrm{C}$ for $48 \mathrm{~h}$ at biotechnology lab of The University of Lahore, Lahore. After it, dry weight of root, stem and leaf was measured in grams by using electric balance.

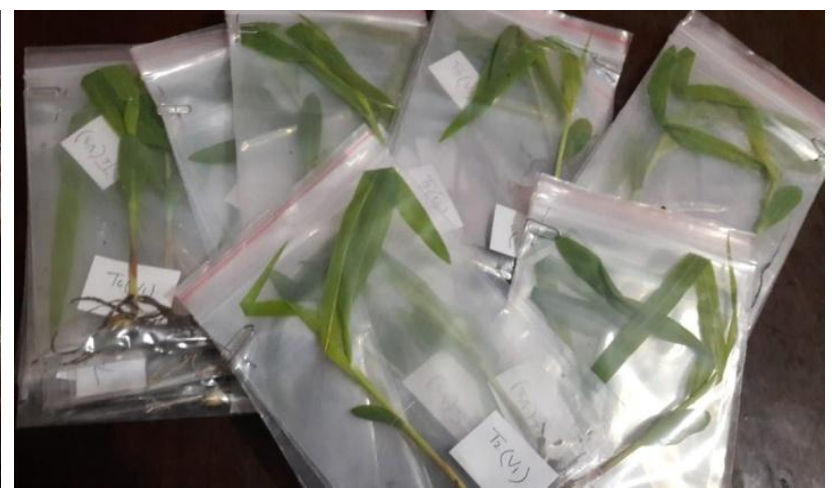

metal stress studies in maize seedlings

2014ab; Ali et al., 2015; Ashraf et al., 2020; Khalil et al., 2020). The genotype Neelum may be selected as heavy metal tolerance genotypes in maize. The treatments of heavy metals caused higher damaging effects on genotype 31R88 (Misra and Jaiswal, 1982; Shankar et al., 2005). It has been shown from results given in table 3 that the high plant height, fresh leaf weight, fresh root weight and dry leaf weight was found under treatment $0.5 \mathrm{M} \mathrm{MnCl} \mathrm{M}_{2}$ indicated that there were very low toxic effects of this treatment. The photosynthetic rate was not affected due to applications of this treatment as compared with the applications of other treatments. While low plant height, dry stem weight, dry leaf weight and diameter of root was found under treatment $0.5 \mathrm{M}$ $\mathrm{MnCl}_{2}+0.25 \mathrm{M} \quad \mathrm{CrCl}_{3}$ and $0.25 \mathrm{M} \quad \mathrm{CrCl}_{3}$ which indicated that there were very high toxic effect of this treatment. The photosynthetic rate was affected due to applications of this treatment as compared with the applications of other treatments. The selection of genotypes under heavy metal treatment of $0.5 \mathrm{M}$ $\mathrm{MnCl}_{2}$ may be helpful for the improvement of crop

[Citation: Shafique, F., Ali, Q., Malik, A. (2020). Effects of heavy metal toxicity on maize seedlings growth traits. Biol. Clin. Sci. Res. J., 2020: 27 doi: https://doi.org/10.54112/bcsrj.v2020i1.27] 
production and productivity (Doncheva et al., 2006;

Barcelo et al., 1985).

Table 1. Analysis of variance for different growth parameters of maize seedlings under heavy metal treatments

\begin{tabular}{llll}
\hline Growth parameters & Average & Coefficient of variation & Statistical analysis \\
\hline Plant height & $8.1459 \pm 3.151$ & 0.27 & Significant \\
L/P & $3.3674 \pm 0.0103$ & 0.84 & Sig. \\
Leaf are & $18.441 \pm 0.3900$ & 0.79 & Sig. \\
Fresh root weight & $0.2789 \pm 0.065$ & 0.24 & Sig. \\
Fresh stem weight & $0.4640 \pm 0.049$ & 0.12 & Sig. \\
Fresh leaf weight & $0.2684 \pm 0.063$ & 0.11 & Sig. \\
Dry root weight & $0.0252 \pm 0.005$ & 1.75 & Sig. \\
Dry stem weight & $0.0200 \pm 0.013$ & 1.66 & Sig. \\
Dry leaf weight & $0.0174 \pm 0.0013$ & 2.43 & Sig. \\
Diameter of root & $0.5218 \pm 0.044$ & 0.55 & Sig. \\
Diameter of stem & $1.3709 \pm 0.086$ & 0.38 & Sig. \\
\hline \multicolumn{2}{c}{ Probability level=5\% } & &
\end{tabular}

Table 2: All pairwise comparison among different maize accessions for different growth parameters $(\mathrm{p} \leq 0.05)$

\begin{tabular}{|c|c|c|c|c|c|}
\hline \multirow[t]{2}{*}{ Growth parameters } & \multicolumn{5}{|c|}{ Maize accessions } \\
\hline & $30 Y 87$ & $31 R 88$ & Neelum & Pak afghoi & White corn \\
\hline Plant height & & - & & + & \\
\hline $\mathrm{L} / \mathrm{P}$ & & & + & - & \\
\hline Leaf area & & - & + & & \\
\hline Fresh root weight & & - & & & + \\
\hline Fresh stem weight & & - & + & & \\
\hline Fresh leaf weight & & - & & & + \\
\hline Dry root weight & + & - & & & \\
\hline Dry stem weight & + & - & & & \\
\hline Dry leaf weight & & - & + & & \\
\hline Diameter of root & & & + & & - \\
\hline Diameter of stem & & - & & & + \\
\hline
\end{tabular}

Negative sig $(-)=$ Highly affected

Positive sig $(+)=$ Less affected

Table 3: All pairwise comparison among different heavy metal treatments for different growth parameters

\begin{tabular}{|c|c|c|c|c|c|}
\hline \multirow{2}{*}{$\begin{array}{l}\text { Growth } \\
\text { parameters }\end{array}$} & \multicolumn{5}{|c|}{ Heavy metal treatments } \\
\hline & Control & $0.5 \mathrm{M} \mathrm{MnCl} \mathrm{I}_{2}$ & $0.25 \mathrm{M} \mathrm{MnCl}{ }_{2}$ & $0.5 \mathrm{M} \mathrm{CrCl}_{3}$ & $0.25 \mathrm{M} \mathrm{CrCl}_{3}$ \\
\hline Plant height & & + & & & \\
\hline $\mathrm{L} / \mathrm{P}$ & & & + & & - \\
\hline Leaf are & & & + & - & \\
\hline Fresh root weight & & + & - & & \\
\hline Fresh stem weight & & & & & - \\
\hline Fresh leaf weight & & + & & - & \\
\hline Dry root weight & & - & & & \\
\hline Dry stem weight & & & & & \\
\hline Dry leaf weight & & + & & & \\
\hline $\begin{array}{l}\text { Diameter of root } \\
\text { Diameter of stem }\end{array}$ & & & + & & \\
\hline $\begin{array}{l}\text { Growth } \\
\text { parameters }\end{array}$ & 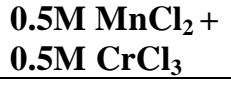 & $\begin{array}{l}0.5 \mathrm{M} \mathrm{MnCl} \\
0.25 \mathrm{MrCl}_{3} \\
\end{array}$ & $\begin{array}{l}0.25 \mathrm{M} \mathrm{MnCl}{ }_{2}+ \\
0.5 \mathrm{M} \mathrm{CrCl}_{3}\end{array}$ & 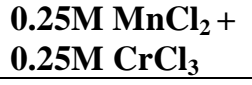 & \\
\hline $\begin{array}{l}\text { Plant height } \\
\text { L/P } \\
\text { Leaf are } \\
\text { Fresh root weight }\end{array}$ & & - & & & \\
\hline $\begin{array}{l}\text { Fresh stem weight } \\
\text { Fresh leaf weight }\end{array}$ & & & & + & \\
\hline
\end{tabular}

[Citation: Shafique, F., Ali, Q., Malik, A. (2020). Effects of heavy metal toxicity on maize seedlings growth traits. Biol. Clin. Sci. Res. J., 2020: 27 doi: https://doi.org/10.54112/bcsrj.v2020i1.27] 


\begin{tabular}{lll}
\hline Dry root weight & & + \\
Dry stem weight & - & \\
Dry leaf weight & - & \\
Diameter of root & - & - \\
Diameter of stem & & \\
\hline
\end{tabular}

Negative sig $(-)=$ Highly affected

Positive sig $(+)=$ Less affected

\section{Conclusion}

Analysis of variance indicated the differences among five different genotypes and 9 different treatments for all parameters were significant. Tukey's test indicated that higher toxic effect was shown under treatment $0.5 \mathrm{M} \mathrm{Mn}+0.25 \mathrm{M} \mathrm{Cr}$ while less toxic effect was observed under treatment $0.50 \mathrm{M} \mathrm{Mn}$ in maize plant. Variety 31R88 was more sensitive for metal toxicity because most of the traits were affected in 31R88 under heavy metal treatments which indicates through negative sign while more tolerant variety was Neelum which indicates through positive significant. Positive sign indicates that plant growth was less affected under heavy metal treatments. Plant growth and photosynthetic rate will be high under heavy metal treatment, while negative sign indicates that growth parameters were highly affected under heavy metal treatments. Plant growth and photosynthetic rate will be low under heavy metal treatments.

\section{Conflict of interest}

The authors have declared absence of any type of conflict of interest.

\section{References}

Ashfaque, F., Inam, A., Sahay, S. and Iqbal, S. (2016). Influence of heavy metal toxicity on plant growth, metabolism and its alleviation by phytoremediation-a promising technology. International Journal of Agricultural Research Impact Factor, 6: 1-9.

Ali, F., Ahsan, M., Ali, Q., and Kanwal, N. (2017). Phenotypic stability of Zea mays grain yield and its attributing traits under drought stress. Frontiers in plant science $\mathbf{8}, 1397$.

Ali, F., Kanwal, N., Ahsan, M., Ali, Q., Bibi, I., and Niazi, N. K. (2015). Multivariate analysis of grain yield and its attributing traits in different maize hybrids grown under heat and drought stress. Scientifica 2015.

Ali, Q., Ahsan, M., Kanwal, N., Ali, F., Ali, A., Ahmed, W., Ishfaq, M., and Saleem, M. (2016). Screening for drought tolerance: comparison of maize hybrids under water deficit condition. Advancements in Life Sciences 3, 51-58.

Ali, Q., Ahsan, M., Tahir, M. H. N., and Basra, S. M. A. (2014a). Gene action and correlation studies for various grain and its contributing traits in maize (Zea Mays L). Bothalia $\mathbf{4 4 ,} 80$ 91.

Ali, Q., Ali, A., Ahsan, M., Nasir, I. A., Abbas, H. G., and Ashraf, M. A. (2014b). Linex Tester analysis for morpho-physiological traits of Zea mays $\mathrm{L}$ seedlings. Advancements in Life sciences 1, 242-253.

Ashraf, A., Rashid, M., Ali, Q., and Malik, A. (2020). Genetic Advances and Heritability Analysis for Seedling Growth Traits in Zea mays under Heavy Metal Stress. Genetics and Molecular Research 19.

Barcelo, J., Poschenrieder, C. and Gunse, B. (1985). Effect of chromium VI on mineral element composition of bush beans. Journal of Plant Nutrition, 8(3): 211-217.

Chaudhary, A.R. (1983). Maize in Pakistan. Punjab Agricultural Research Coordination Board, University of Agriculture Faisalabad.

Demirevska-Kepova, K., Simova-Stoilova, L., Stoyanova, Z., Hölzer, R. and Feller, U. (2004). Biochemical changes in barley plants after excessive supply of copper and manganese. Environmental and Experimental Botany, 52: 253-266.

Doncheva, S., Stoyanova, Z., Georgieva, K., Nedeva, D., Dikova, R., Zehirov, G. and Nikolova, A. (2006). Exogenous succinate increases resistance of maize plants to copper stress. Journal of plant nutrition and soil science, 169(2): 247-254.

Khalil, M., Rashid, M., Ali, Q., and Malik, A. (2020). Genetic Evaluation for Effects of Salt and Drought Stress on Growth Traits of Zea mays Seedlings. Genetics and Molecular Research 19.

Mazhar, T., Ali, Q., and Malik, M. S. R. A. (2020). Effects of salt and drought stress on growth traits of Zea mays seedlings. Life Science Journal 17.

Misra S.G., and Jaiswal, P.C. (1982). Absorption of Fe by spinach on chromium (VI) treated soil. Journal of Plant Nutrition, 5(4-7):755-60.

Mohnish, P., and Kumar, N. (2015). "Effect of Copper Mining Dust on the Soil and Vegetation in India: A Critical Review". International Journal of Modern Sciences and Engineering Technology (IJMSET), 2: 7376.

[Citation: Shafique, F., Ali, Q., Malik, A. (2020). Effects of heavy metal toxicity on maize seedlings growth traits. Biol. Clin. Sci. Res. J., 2020: 27 doi: https://doi.org/10.54112/bcsrj.v2020i1.27] 
Nkansan, M. A., and Amoako, C.O. (2010). Heavy metal content of some common spicies available in markets in the in the Kumasi metropolis of Ghana. American Journal of Scientific and Industrial Research 192:158-163.

Rakesh, S., and Raju, N.S. (2013). Correlation of Heavy Metal Contamination with Soil Properties of Industrial Areas of Mysore, Karnataka, India by Cluster Analysis. International Research Journal of Environment Sciences, 2: 22-27.

Saif-ul-malook, M. A., Ali, Q., and Mumtaz, A. (2014). Inheritance of yield related traits in maize (Zea mays) under normal and drought conditions. Nat Sci 12, 36-49.

Salt, D.E., and Rauser, W.E. (1995). Mg ATPdependent transport of phytochelatins across the tonoplast of oat roots. Plant Physiology, 107: 1293-1301.

Shan, C., Liu, H., Zhao, L., and Wang, X. (2014). Effects of exogenous hydrogen sulfide on the redox states of ascorbate and glutathione in maize leaves under salt stress. Biologia plantarum 58, 169-173.

Shanker, A.K., Cervantes, C., Loza-Tavera, H., and Avudainayagam, S. (2005). Chromium toxicity in plants. Environment international, 31(5): 739-753.

Sheng, M., Tang, M., Chen, H., Yang, B., Zhang, F., and Huang, Y. (2008). Influence of arbuscular mycorrhizae on photosynthesis and water status of maize plants under salt stress. Mycorrhiza 18, 287-296.

Tahir, M., Rashid, M., Ali, Q., and Malik, A. (2020). Evaluation of Genetic Variability in Wheat and Maize under Heavy Metal and Drought Stress. Genetics and Molecular Research 19.

Zubair, M., Shakir, M., Ali, Q., Rani, N., Fatima, N., Farooq, S., Shafiq, S., Kanwal, N., Ali, F., and Nasir, I. A. (2016). Rhizobacteria and phytoremediation of heavy metals. Environmental Technology Reviews 5, 112119.

\section{(c) (1) 8}

Open Access This article is licensed under a Creative Commons Attribution 4.0 International License, which permits use, sharing, adaptation, distribution and reproduction in any medium or format, as long as you give appropriate credit to the original author(s) and the source, provide a link to the Creative Commons licence, and indicate if changes were made. The images or other third party material in this article are included in the article's Creative Commons licence, unless indicated otherwise in a credit line to the material. If material is not included in the article's Creative Commons licence and your intended use is not permitted by statutory regulation or exceeds the permitted use, you will need to obtain permission directly from the copyright holder. To view a copy of this licence, visit http://creativecommons.org/licen ses/by/4.0/.

(C) The Author(s) 2021

[Citation: Shafique, F., Ali, Q., Malik, A. (2020). Effects of heavy metal toxicity on maize seedlings growth traits. Biol. Clin. Sci. Res. J., 2020: 27 doi: https://doi.org/10.54112/bcsrj.v2020i1.27] 